\title{
What Is Neutral about Neutrality?
}

\author{
Bruce A. Ackerman
}

Neutrality: a fighting word. Only neuters can be Neutral in politics. The fool who yearns for Neutrality indulges a special kind of silliness - from which libertarians and communards, Maoists and Straussians are mercifully immune. There can be no politics without vision, no philosophy without commitment. Neutrality is not just another political slogan. If taken seriously, it will destroy the most distinctive feature of politics: the impossibility of reducing it to a neutral science of social engineering. Until the liberal is disabused of his absurd search for a value-free politics, his "philosophy" will remain a contemptibly superficial, if surprisingly seductive, exercise in suppression.

This theme emerges only more emphatically for the different variations which are played out in the preceding pages. Despite their differences from one another, each symposiast raises questions Neutrality cannot answer-lest anyone mistake my piece of science fiction for the liberal's long-sought heavenly city. In response to my effort to reinvigorate Neutrality, my commentators reassure themselves that the liberal's image of a value-free politics remains a mirage.

This is, of course, the way of all good conversations - for every Yes, a doubting But; for every No, a hopeful Maybe. But there is a special reason to welcome the conversational turn here. In raising a well-worn banner, I did not wish to make the same old liberal mistakes. A value-free politics seems no less absurd to me than to my most critical critic. Rather than somehow depoliticizing politics, Neutrality permits liberals to gain a deeper philosophical perspective on their own more obvious commitments and anxieties.

This, at least, is my hope. And I am glad to report that my fellow symposiasts have not deprived me of it. By enumerating problems Neutrality cannot solve, they have not persuaded me that the questions Neutrality can answer are unimportant. Instead, they have helped fill the agenda of liberal philosophy with fresh questions that seem well worth the asking.

\section{POSSIBLE COMMUNITIES}

Barber's microdramas present a stark choice-either we may enjoy the pleasures of unconstrained conversation with the likes of Fred Broome and Juliet Capulet or we can condemn ourselves to the tedious monotony of Neutral dialogue. Given these alternatives, Barber's judgment is hardly surprising: "Neutrality destroys dialogue." This conclusion, however, is no better than the false dichotomy upon which it is based: can't we engage in both constrained and unconstrained dialogue, shifting the conversational key as the occasion requires? Can't we play credible roles within different dialogic structures?

Ethics 93 (January 1983): 372-390

(C) 1983 by The University of Chicago. All rights reserved. 0014-1704/83/9302-0013 $\$ 01.00$ 
Surely Barber is the last person who can afford to deny this: his craft as a dramatist depends upon it. The task is to define the precise relationship between Neutral and un-Neutral talk in a way that lays to rest Barber's anxieties about the future of dialogue in the liberal state. To do this, I shall require a technical term. To introduce the idea, suppose you meet a friend of an afternoon and each of you tries to launch the conversation in a different direction. Say, he wants to tell you about the movie he just saw, while you want to talk about the place you should go for dinner. The conversation is, temporarily, at an impasse: who will defer to whom in the choice of conversational topic?

It is here that the idea of a conversation stopper comes into play. Either I stop you or you stop me or the conversation degenerates into a host of random ejaculations on this and that. To avoid dialogic chaos, we are all adepts in a complex set of conventions through which we allocate conversation-stopping authority. And it is these conventions I mean to build upon in describing the structure of conversation in a liberal state.

Suppose, this time, your friend approaches you with something more portentous than a movie review: he wants, instead, to review the progress of your life, tell you how you ought to live in the future, and so forth. What are friends for if not to talk about such things?

There is only one problem. While this friend of yours calls himself your "friend," you do not. Indeed, you think it a waste of time to talk to such an obtuse busybody. Rather than continuing his ultimate conversation, you try to begin the penultimate one: what gives you the right to tell me how I ought to live my life?

It is here that the question of conversational authority arises. Should my "friend" be allowed to stop my penultimate question, force me to engage in his conversation, and impose sanctions upon me if I fail to agree with his ultimate conclusions? Or shall I be given the right to stop his ultimate conversation and insist upon an answer to my penultimate question?

The liberal's answer is clear and unconditional. Call it the principle of conversational priority: the simple act of raising the penultimate question always serves as a conversation stopper. By guaranteeing each citizen the sovereign right to change the topic of conversation, the liberal provides a vital dialogic defense against all who would impose their ultimate answers upon us without our consent. There will be unconstrained conversations aplenty in the ideal liberal state. But none will be imposed unilaterally; all will pass between citizens who had the conversational right to stop further talk with a thin: "Alas, my friend, you are wasting my time. While, doubtless, you find your variety of ultimate conversation enlightening, it means nothing much to me. And am I not at least as good a judge of such matters as you are?"

It is precisely these lines that have eluded Barber's "unconstrained" conversationalists. Begin with Romeo and Juliet. Surely no liberal would wish to deny Barber his triumphant first act-in which the happy couple transcend speech in ecstatic embrace. Yet Barber gains this dramatic victory only by emptying his story of tragic content. At no point does he allow the elder Montagues and Capulets the chance to challenge their children's wanton disobedience. Nor does Barber even hint at the script he might write if he pacified Shakespeare's ghost by allowing the enraged parents their moment on the stage.

I cannot believe, though, that Barber would content himself with a cheap dialogic victory-in which enraged parents or happy lovers compel their opponents 
into a quick renunciation of their deepest beliefs. At the very least, he would search out some non-Shakespearean way of expressing the tragedy of such forced convers(at)ions. But in doing so, he would be making the liberal point-legitimate community is not to be achieved through conversation in which one party unilaterally imposes his ultimate answer upon his dialectical foil. It can only be gained if the protagonists recognize the depth of their ultimate disagreement by stopping, at least for a time, to consider penultimate questions: why do the elder Montagues and Capulets think they have a right to impose their ultimate answers on their children? Why do Romeo and Juliet think they have a right to impose their answer on their parents?

Not that the liberal promises a happy ending to all who make this conversational turn. Romeo and Juliet may come to regret the victory they gain over their parents by insisting on their liberal rights in a constrained conversation. Bedroom bliss may fade only to reveal the deep spiritual antipathies that have set Montague apart from Capulet for generations. The end of the liberal drama may be no less tragic or complex than the death scenes Shakespeare has given us.

We are certain of only one difference. In the Shakespearean script, Romeo and Juliet die in an effort to transcend the place assigned them by their parents. In the liberal script, they will die only if they are unable to live with the consequences of their dialogic liberation from their parents: while the young couple may make a mess of their lives, it is they who set the stage for their own tragedy by insisting upon their sovereign right to stop their parents' ultimate conversation. The final moments of the liberal script, in short, reveal Romeo and Juliet as the authors of their own tragedy. While this ending does make for distinctive drama, it hardly suggests that "neutrality destroys dialogue."

But we should not merely ring liberal changes on Romeo and Juliet. Undue concentration on this archetypal tragedy of romantic individualism gives substance to the familiar complaint that liberalism allows only for an alienating kind of freedom that destroys all hope of community. To confront this canard, turn to another of Barber's pregnant microdramas - the one in which proletarian Fred Broome and professor Bruce Ackerman try to cut Yale's budget in a way that does justice to their common fellowship within the university.

Once again, Barber cuts off his "unconstrained conversation" before Fred and Bruce attempt the tricky business of hammering out a common understanding of their roles within the university. Suppose, for example, that his unwritten Second Act reveals a compelling story of failed communication-ending with Bruce or Fred (or both) leaving New Haven in a black rage at Yale's betrayal of academic excellence or social justice (or both). How, then, is Barber to write his Third Act? Does his commitment to community authorize the Yalies to force the renegade Blue to continue his appointed role in the Yalish order of things?

If so, he has indeed reached a dramatic turning point. The liberal principle of conversational priority requires the True Blues to respect the conversation stopper raised by the excommunicant and allow him to leave New Haven in search of community elsewhere. In requiring this dialectical move, liberal principles do not trivialize the high importance of the search for ultimate community. To the contrary, liberal dialogue serves as a check only upon oppressive forms of community-ones that could not exist if all members were given the right to stop further communication with an emphatic: What right do you have to tell me what to do-am I not at least as good as you are? 
But suppose, as I very much hope, that Barber can write a happier Second Act. Rather than Bruce or Fred losing a bitter struggle for Yale's soul, the unfolding script displays a credible communitarian success - in which we all get together to cut the Yale budget in a spirit of mutual sacrifice and common understanding. Nonetheless, the Third Act remains a problem.

Here the spiritually renewed Yalies confront the unhappy fact that Yalopolis is but a tiny island in the deep blue sea of humanity. Worse yet, the barbarians perversely fail to recognize Yale for the grand thing it is. They gather before the gates demanding a share in Yale's riches. Before storming Harkness Tower, however, they are good enough to raise the question of legitimacy: Why should the Yalies of the world command resources that others also desire?

I do not know how Barber proposes to write his way out of this dramatic difficulty. Perhaps he has a battle scene in mind-Bruce and Fred charging from Harkness Tower to slaughter the barbarians who have, by their very question, profaned the self-evident goodness of Yalopolis? Or perhaps he will close with the conversion of the heathens - Bruce and Fred convincing the gathering horde to assume their rightful places in the order ordained by God, Country, and Yale? Or perhaps -is this an implication of the dialogue between David Stockman and George Washington Johnson?-Bruce and Fred gain peace by buying off the worst troublemakers, promising their children special admission into Yaledom if they will only keep quiet?

Rather than "destroying dialogue," it is precisely here where the liberal affirms its continuing significance. After all the familiar forms of communitarian rhetoric have played themselves out, Neutrality permits a polis-like community to find a voice when dealing with the outsiders beyond the gates who will inevitably challenge their status as outcasts. By respecting the liberal principle of conversational priority, people on both sides of the communal frontier can continue to talk to one another in the accents of self-respect. Setting aside, for a time, their ultimate disagreements, they may build a larger political community through the art of constrained conversation.

It is, as Bernard Williams rightly emphasizes, the thinnest form of communityone that does not depend upon a successful appeal to love or sympathy or even common interest. Liberal community is instead grounded on the simple desire to communicate. ${ }^{1}$ Despite profound differences in our ultimate ideals, we need not look upon one another as utterly alien and repugnant beings fated to occupy the same planet until one or the other of us is exterminated. Instead, we can find a way of talking to one another without lying about the fact of our ultimate disagreement. Neutral dialogue, in short, marks the boundary of the most extensive form of dialogic community-embracing all who can participate in a mutually intelligible effort to control the power struggle that is their common predicament.

1. It is for this reason, among others, that I think it is past time for Anglo-American liberals to control their knee-jerk reaction to all things Continental and actually try to take the Germans and French seriously. Rather than kicking Habermas and others around, we should recognize that they are absolutely right to insist on the intimate relationship between community and communication. I do not deny, of course, that it is awfully hard to translate their books into a philosophical idiom that is congenial to Anglophonic sensibilities. Yet, as Albert Weale suggests in a thoughtful review of my book, the effort can be rewarding (see his review of Social Justice in the Liberal State, by Bruce Ackerman, Minnesota Law Review 65 [1981]: 685-99, esp. 689-92, 699). 
Yet, however extensive the ideal liberal community, membership does have limits. And Barber is right to test these limits in the liaison with Adolf Hitler he has arranged for me. The liberal's theory of citizenship is categorically opposed to the Nazi's. Membership in the liberal polity depends upon neither biology nor physical appearance, but on culture. The critical question, in all cases, is not what a candidate looks like, but how he communicates - in particular, whether he can participate as an independent actor in a Neutral dialogue defining a legitimate solution to the power struggle. ${ }^{2}$

Since Hitler categorically disagrees with this theory, Barber is right to think that the Führer would take special pleasure in rejecting liberal citizenship by manipulating the very terms in which it is offered. I fear, however, that Barber's Hitler is unequal to the dialectical challenges of this demanding role. Rather than some brave declaration of independence, Hitler's rejection of liberal citizenship is based upon a garden variety mistake. "Since I'm at least as good as a Jew, I should get at least as much stuff as the Jew does." Hitler reads these lines as implying that Jews may have a little bit of "goodness"-a possibility he vehemently denies. But in doing so, he is rejecting an assertion he need never make as a liberal citizen. Since more thoughtful readers may labor under a similar misapprehension, ${ }^{3}$ I shall restate the liberal argument in a way that omits all mention of "goodness." Thus, if it will suit Hitler's disposition better, let him say this: "Surely I'm no worse than this [epithet] Jew! Since this is so, my claims to power are certainly entitled to no less weight than his are." Hitler, in short, need affirm only a purely ordinal judgment before his claim to citizenship is accepted. Moreover, I cannot agree with Williams's A when he says that, in making this claim, the citizen is obliged to speak in an "unspecific or indeterminate" way (p. 368). While ordinal judgments contain less information than cardinal comparisons, my book establishes that they are sufficiently "determinate" to generate rather specific conclusions in a liberal dialogue about social justice. Nor is it right to say that ordinal statements require the citizen to "say less than [he] believe[s]" (p. 368). If Hitler believes anything, he believes that he is no worse than a Jew. Of course, Hitler believes other things as well; but he fully believes what he says in the liberal conversation. Despite his best efforts, Barber's Hitler has not broken the linguistic ties that bind him to the liberal community. He can speak with his own voice in a dialogue that is constrained by the Neutrality principle and so is entitled to recognition as a liberal citizen ${ }^{4}$ — though, of course, his fellow citizens are entitled

2. Ackerman (cited in the introduction to the symposium), chap. 3; hereafter cited in the text as Liberal State.

3. It afflicts, e.g., the persona Bernard Williams calls A (see p. 367 above). A's views are discussed in the succeeding paragraphs of the text and in $n .4$ below.

4. While Williams's A is a very different character from Barber's Hitler, he too is led astray by his failure to distinguish between ordinal and cardinal judgments. According to A, Neutral dialogue gives a privileged position to the substantive views of people who "really think that someone else's conception of the good was just as good as her own" (p. 368). To see why this is false, consider that A's egalitarian is not content with the weak ordinal claim that her good is no worse than others'; she insists on the stronger, cardinal judgment that her ideals contain precisely the same amount of "goodness" as those affirmed by her competitors. Yet it is precisely this cardinal move that is unnecessary in Neutral conversation: when the liberal makes the ordinal claim that the pursuit of his good is at least as good as another's, he is not making the cardinal assertion that it is just as good. It follows that $\mathrm{A}$ is wrong in suggesting that Neutral dialogue gives "cardinal" egalitarians 
to protect themselves against his aggressive assaults on their liberal rights (Liberal State, § 19).

This is not to say that the declaration of independence for which Hitler yearns is a dialectical impossibility. It is merely to recognize that, once again, Barber has left his drama unfinished. By letting a common lout like Hitler monopolize attention, he deprives Nietzsche of his rightful place on the stage. In suppressing Nietzsche, however, Barber does liberalism no real service-for it is only after a personal confrontation with Nietzsche's negations that the thoughtful liberal may even hope for a sense of dialectical resolution.

\section{POSSIBLE WORLDS}

But it is not enough to define the relationship between liberal conversation and the universe of unconstrained discourse. Standing by itself, Neutral dialogue simply specifies an ideal decision procedure: it tells citizens how they must resolve their conflicts if they are to hope for liberal legitimacy. Before the procedure may be put to work, it must be imbedded in one or another model of the power struggle. As Fishkin, Flathman, and Williams all rightly emphasize, I can explain how liberal citizens can resolve their disputes only after I have described what it is they are struggling over.

Now there is only one model of the power struggle that is, ultimately, of interest to me. And that is the model which most accurately describes the world in which we actually live. But an accurate description of our world-and its particular possibilities for political transformation-is a notoriously difficult and controversial business. As a consequence, my book begins with an effort to describe a possible world in which citizens were completely successful in mediating their power struggle through Neutral dialogue.

In making this Utopian leap, I hoped to avoid landing in a familiar perplexity. Freed from the struggles of real life, it is all too easy to daydream about a world that is radically unlike any place any earthly creature might possibly inhabit: Rawls's "original position" serving as the most recent in a never-ending series of never-never lands. In advancing a model of the power struggle to serve as the framework for systematic analysis, I hoped to avoid such escapist fantasies. Rather than inviting my reader to pass judgment on his mundane struggles by pretending to the wisdom of some unearthly inhabitant of some translunar place, my aim was to force readers to confront some familiar earthly problems without the aid of a familiar evasion. All too often, discussions of basic principle get bogged down in the practical difficulties involved in implementing policy in a complex and uncertain world. While these pragmatic discussions are of great importance, it is no less important to gain as much clarity as we can about the ultimate ideals that should govern the complex craft of liberal statesmanship.

It was the aim of my "ideal" theory to focus upon this latter question by imposing a temporary conversational stop upon all questions involving implementation (Liberal State, $\S 8$ ). Deferring all such issues to the "second best" theory in the second half of my book, I allowed my imagination full reign when it came to designing a perfect "technology of justice"-perhaps "ideal legal system" would have been a better term - to assure the costless implementation of the results of Neutral dialogue. In modeling the basic features of the earthly power

explicit support in their ongoing ultimate conversation with those fellow citizens who believe that some ideals are inherently superior to others. 
struggle, however, I allowed myself no similar liberties. Instead, I focused upon a set of unavoidable decisions that inevitably shape Everyman's fate as he struggles through life as we know it (Liberal State, § 23).

My model begins at the earliest possible moment at which a social decision might affect Everyman's worldly power position-the moment Everyman is endowed with a particular combination of genetic materials: how are we to decide which babies will be conceived and which genetic permutations will go unrealized? Everyman's biography proceeds to the time he is educated by his elders into particular patterns of culture: who will socialize Everyman into which patterns of "good" behavior? We continue onward to the point at which Everyman is sufficiently socialized to assert his right to control some portion of material reality: to how much is he entitled? This question resolved, adult Everyman confronts a transactional structure that enables him to engage in some transactions far more easily than it permits him to engage in others: when, if ever, may he insist on restructuring his transactional opportunities in the name of social justice? And finally, after he has made something-or-other of his life, there is death. Should the liberal community allow Everyman to transfer his inheritance to anybody he wishes?

It is this five-part biography that sets the conversational agenda for liberal theory. As a mnemonic device, I thought it useful to devise five labels to summarize the dialogic conclusions reached in response to each of the five problems: hence, I speak of liberalism's commitment to principles of undominated genetic diversity, liberal education, equal material resources, perfect transactional flexibility, and liberal trusteeship. These five labels, however, are not to be given lives of their own; they are merely placeholders for dialogic conclusions reached by liberal citizens confronting one or another problem provoked by the Everyman story. Similarly, the master liberal doctrine - undominated equality-is merely an umbrella term referring to all the conclusions reached through the Neutral dialogue generated by all five power problems.

Given the critical role of the five power problems, James Fishkin shows a sound critical instinct in focusing on questions raised in their definition. I fear, however, that his critique has been deflected by a misplaced Rawlsian analogy. An important part of $A$ Theory of Justice is Rawls's effort to develop a "thin" theory of the good: it is these, and only these, "thin" goods that must be distributed to the advantage of the worst-off. While Rawls's book was tantalizingly obscure in explaining his "thin" theory, Fishkin is right in thinking that his recent Dewey lectures $^{5}$ clarify things for the worse. Rawls now expressly pours substantive content into his maximin principle with the aid of a very particular conception of "a moral person"-one that requires the acceptance of a host of very controversial neo-Kantian presuppositions. In so doing, Rawls opens himself up to the full force of Fishkin's critique.

In contrast, my method of pouring content into "undominated equality" does not commit me to any particular theory of "a moral person," Kantian or otherwise. Instead, I have filled in the requirements of "undominated equality" with the aid of a model that describes the power struggle in which any persongood or bad-finds himself as a resident of our planet. This different procedure permits a distinctive response to Fishkin's criticisms.

5. John Rawls, "Kantian Constructivism in Moral Theory: The Dewey Lectures 1980," Journal of Philosophy 77 (1980): 515-72. 
To see this, consider the remarkable ways in which my enterprise would be transformed if I took Fishkin's critique to heart and eliminated the features of "undominated equality" that he considers "arbitrary"(p.352). Suppose, for example, that Fishkin persuaded me to give up measuring undominated equality in terms of "manna" and that I responded by eliminating the chapter on this subject from The Liberal State. Since "manna" serves as a placeholder embracing all material objects (except those considered in the dialogues about genetic, educational, and transactional resources), my truncated book would have restricted itself to the report of Neutral dialogues occurring in a largely immaterial world. Surreality would be complete if I also were convinced that it was "arbitrary" to deal with the struggle over genetic endowments, eliminating the chapter on undominated genetic diversity. Since "genes" are understood as a program defining each citizen's possible bodily behaviors, the elimination of this chapter would imply a concern with the conversational practice of purely spiritual beings!

Fishkin is on slightly firmer ground in questioning my decision to focus attention on the distribution of "educational" and "transactional" resources. It is possible, after all, to imagine an earthly world inhabited by liberal citizens who have no need of "education"-so long, that is, as our model stipulates that the citizenry never suffer through childhood but spring full-blown into maturity, in the manner of Pallas Athena. It is even easier to imagine a world inhabited by Robinson Crusoe (without Friday) who could do without any transactional structure. But it is obvious that none of my readers will ever live in such a world-and that traditional liberal theory has greatly weakened itself by indulging in such fantasies.

And as for my decision to conclude the struggle for power with the moment of Everyman's death, I could have omitted the problem of inheritance only if my model had endowed each liberal citizen with immortality. But this promise, alas, forms no part of the inducement to a liberal politics.

Fishkin would have been better advised to look to Hume, rather than Rawls, in his effort to understand my definition of "undominated equality." In some famous passages, Hume describes the features a world must possess before it would make sense for its inhabitants to take the question of justice seriously. It is only such "Humean" features that I mean to presuppose in designing the model of the power struggle that generates the five problems on my liberal citizenry's conversational agenda.

Not that Hume's particular statement of the preconditions for justice-talk should serve as the last word on the matter. As I read him, Hume focused entirely upon controversies of the manna-like variety-in which a plurality of adult citizens are struggling over a scarce supply of material resources. Indeed, he explicitly states that all talk of justice would be pointless in a world in which material scarcity had been overcome. ${ }^{6}$ In contrast, my model of the power struggle would still give the citizens of Cornucopia some important things to talk about: notably, the genetic and cultural endowments of the next generation. The power struggle concerning these matters is not generated by material scarcity, but by an embarrassment of riches. Simply put, we can give our children any one of a very large number of cultural inheritances; and increasingly, we will enjoy a similar

6. David Hume, A Treatise of Human Nature, ed. L. A. Selby-Bigge and P. H. Nidditch (Oxford: Clarendon Press, 1978), bk. 3, sec. 2, pp. 494-95. David Hume, An Enquiry concerning the Principles of Morals, ed. L. S. Selby-Bigge (Oxford: Oxford University Press, 1975), sec. 3, pt. 1, pp. 183-84. 
power over their genetic endowments. Yet, somehow, generation one must transmit one-and only one- of the countless genetic and cultural inheritances that could provide the foundation for generation two's life on this planet. And, of course, different members of generation one will struggle over the way in which this power over genes and education should be exercised. How, then, are they to resolve the ensuing disagreement?

My exercise in ideal theory, in short, contains two different kinds of novelty. On the one hand, my statement of the problem of justice goes beyond the familiar Humean account: in addition to their struggle over scarce material commodities, my citizens confront the embarrassment of riches generated by genetic and educational policy. On the other hand, my specification of the solution to the problem differs from familiar proposals: rather than appealing to contract or utility, liberal citizens try to resolve each of their power problems by talking to one another in a Neutral way. In making both of these moves, I open myself up to a host of criticisms. It would clarify matters, however, if criticisms directed at one novelty were not confused with those directed at the other.

This confusion lies at the bottom of Fishkin's charge that I play fast and loose with Neutrality in the course of developing my dialogues. Fishkin's first serious complaint is with my treatment of the struggle for "manna." In rejecting a utilitarian solution, I claim that the collective effort to articulate a public conception of "happiness" will inevitably lead the citizenry to conversational moves that violate Neutrality (Liberal State, § 13). While Fishkin does not deny this, he complains that I never permit my citizens to subject "manna" to the same test of strict dialogic Neutrality under which "utility" is found wanting. It is this refusal to expose my own descriptive terms to the test of Neutral dialogue that, according to Fishkin, represents a "loosening" of the Neutrality constraint.

But in advancing this criticism, Fishkin is making the category mistake I have just described. Rather than "loosening" the Neutrality requirement, my decision to focus upon "manna" emphasizes that liberals are interested only in dialogues passing between bodily creatures struggling over material things. If I had taken Fishkin's question about the existence of "manna" seriously, I would only succeed in putting into question the very conditions under which the question of social justice has a point.

In contrast, when a latter-day Benthamite argues on behalf of utility-maximization, he is engaged in a more controversial activity. While a term like "manna" serves as an essential element in a Humean account of the problem of justice, "utility" merely serves to mark out one of a number of possible answers to the problem. By requiring the polity to make interpersonal comparisons of "utility," the utilitarian inevitably offends some of his fellow citizens' conceptions of the good; by requiring the polity to recognize the existence of a struggle over manna, the Humean simply requires the polity to take note of a problem that gives talk of justice its political significance.

A more interesting form of the same confusion lies at the bottom of Fishkin's second complaint. Here he finds me inconsistent in insisting upon equality in the distribution of material resources while I am content with undominated diversity in the distribution of genetic endowments. Fishkin is quite right to detect a shift in the liberal conversation as it moves from material to genetic resources. $\mathrm{He}$ is wrong, however, in his characterization of the kind of change that has taken place. Rather than a shift from "strict" to "loose" Neutrality, what is at stake is 
the shift from a Humean to a post-Humean understanding of the preconditions for justice-talk.

To make this clearer, contrast two problems from ordinary life that precisely parallel the grander issues at stake in the distribution of manna and genes. Suppose, first, that we arrive at dinner to find that a single meat pie has already been provided for us by our parents (who have, unhappily, gone out for the evening). Before each of us can decide how we may best eat the pie, we must confront the familiar Humean problem-how to divide the pie fairly when we are all quite hungry. It is this problem that serves as the model for the struggle over manna-only, now, the pie consists of all the material things that Nature, together with our parents, have been good enough to leave us. In contrast, the distinctive problem raised by the struggle over genetic endowments is generated by an embarrassment of riches. Here, we are to imagine ourselves stationed in the kitchen confronting a large number of genetic ingredients that we may combine in any number of ways to cook up the stew in which the next generation will find itself. We are not now concerned with justice in dividing a pie but with the legitimate way of choosing the $\operatorname{cook}(\mathrm{s})$ as well as their recipe(s).

Given the post-Humean character of the problem, we cannot content ourselves with repeating the liberal solution to the pie-cutting problem. We must instead search for a liberal way of narrowing down the set of possible genetic recipes without requiring the polity to judge the merit of its citizens' conflicting conceptions of the good. It is this concern that motivates the theory of genetic justice developed in my book. While my dialogues on genetic domination are certainly controversial, Fishkin does not question the Neutrality of the particular scripts I have produced. He merely emphasizes that the scripts differ from those involved in the manna dialogues. But this, by itself, is hardly surprising, since the power problems provoking the conversations have a fundamentally different form. Indeed, it would have been far more suspicious if my kitchen conversations had been identical, in all respects, to my dining room talk.

Not, mind you, that Fishkin isn't on to something important in his juxtaposition of genes and manna. Rather than discovering a difficulty with Neutrality, however, he has glimpsed a formidable challenge raised by the movement beyond a Humean fixation on material scarcity as the sole problem for the theory of justice. To restate Fishkin's problem, as I understand it: if Hume's preconditions of justice are radically incomplete, are there not a host of different ways of completing the account? Why did I choose to model Everyman's struggle for power with the aid of my five-part biography? Could I not have fixed upon a very different way of modeling the course of Everyman's struggle with life? How can I justify the selection of my particular post-Humean model?

Part of my answer is the principle of nonpreclusion: a good model's description of the power struggle should not render it definitionally impossible for citizens of the model-world to engage in kinds of power struggle that are empirically possible in our own world. The reason for this principle seems obvious. A preclusive model permits the theorist to escape embarrassing questions raised by the realworld power struggle simply be defining these problems out of existence (Liberal State, pp. 108-9).

Yet, while we must avoid preclusion, liberal philosophy will be overwhelmed if it tries to adjudicate a host of contingent facts and particular power struggles. If we are to gain a comprehensive view of liberal ideals, we must content ourselves 
with a model that expresses the fundamental features of the power struggle in very abstract and general terms.

It is the function of the Everyman story to provide this abstract account. Ideal theory analyzes the justice of any particular conflict in terms of the power provided each participant by: (a) his genetic constitution; $(b)$ his educational background; $(c)$ his initial material endowment; and what he has made of $a, b$, and $c$ by virtue of the opportunities provided him since maturity by $(d)$ his transactional structure. Within this schema, any particular outcome is just if, but only if, each participant can defend his right to achieve his desired outcome by justifying the position accorded him by the power quadruple, $(a, b, c, d)$, in a Neutral dialogue. An ideal liberal state is a place where this dialogic challenge can be met by each and every citizen concerning each and every use he makes of his power position.

Fishkin fails to reckon adequately with the abstract and general character of this framework, frequently treating one or another particular power struggle as if it cannot be accommodated within my more abstract account. For example, he seems to believe that my model cannot deal with each citizen's struggle for rights to good health (p. 354) or long life. But this is simply a mistake. Everyman's health and longevity are not independent of the way he uses the genetic, educational, material and transactional resources placed at his disposal. Indeed, I find it impossible to think of a way society might affect a citizen's good health which did not fall under one or another of these abstract power variables. Since my liberal dialogues address each of these variables in turn, it follows that I have laid a nonpreclusive foundation for a more particularized analysis of rights to health and longevity.

Thus, in ideal theory, some people will use their basic resources in ways that yield long and healthy lives while others will find value in short and unhealthy ones. So long as each began under conditions of undominated equality, neither the Healthy nor the Unhealthy can force one another to confess the error of their ways; nor can the Unhealthy force the Healthy to help pay their "burdensome" medical insurance premiums; nor can the Healthy impose special taxes on the Unhealthy for their "excessive" hospital use. Any effort at special subsidy or special taxation will confront the familiar conversation stopper raised by the other side (Liberal State, pp. 82-86).

As always, the crystalline clarity of these conclusions is clouded by the mists of second best. The critical question here is whether one or another kind of morbidity or mortality can be attributed to illegitimate forms of genetic handicap, initial poverty, illiberal education, or transactional unfairness. It is here where the liberal theory of exploitation (Liberal State, chap. 8) requires aggressive efforts at compensating victims of injustice. Doubtless the design of a just compensation system will generate countless issues upon which liberal statesmen may differ in good faith. It is precisely for this reason that ideal theory restricts itself to the dimensions of the power struggle that will haunt Everyman so long as he continues to struggle on this planet-leaving the analysis of rights to "good health" and other particular outcomes to the theory of liberal statesmanship, sketched in the second half of the book.

Yet, even when the abstract and general character of my post-Humean model is conceded, a question remains: is it as nonpreclusive as is possible to conceive? One of Fishkin's suggestions points to an even leaner conceptual model. Rather 
than breaking up the power struggle into my four analytic components, why not "lump these [four power domains] all together?" (p. 354).

This modeling decision would allow the description of a power struggle that has been precluded by my more complex model. In particular, citizens of the revised model-world could now consider Fishkin's proposal to "permit inequalities in one [power domain] to compensate for inequalities in another (as a matter of ideal theory rather than second best)" (p. 354). Fishkin fails to reflect, however, upon the odd world he must hypothesize before his proposal might seem an appropriate subject for political conversation. In the world as we know it, Everyman's status in the power structure is not determined at a single moment in time, but in a series of fixed developmental stages. Thus, Everyman is conceived before he is educated, educated before he can assert his right to material endowments. . . Each of us comes to the later stages in this sequence irrevocably shaped by the social decisions made at the earlier ones. If, then, a liberal polity breaches the Neutrality constraint when dealing with a future citizen's genetic endowment or cultural inheritance, these illiberal conversations operate to condition all future dealings with him over time. Fishkin's reductionist model would permit the liberal Assembly to ignore this fundamental point. It would allow the Assembly to trade off genetic domination against educational enrichment without recognizing that dialogic injustice, once done, can never be entirely undone. The only world in which such trade-offs might be tolerated in ideal theory is one where all citizens were born already provided with a complete cultural, as well as genetic, endowment. For it is only then that Everyman-better, Everygod-could not point to a time at which his status had been determined by an illiberal political dialogue.

But this is to say that my more complex story does not offend the nonpreclusion principle-for that principle only requires the model to permit the discussion of all Earthly possibilities and does not go further to require the modeling of Pallas Athena fantasies. So long as we are trying to express the order of things as they arise in this world, we should work with a model that requires us to avoid inflicting dialogic injustice upon Everyman at each and every stage in his development. While our failure to fulfill this liberal ideal will sometimes lead to deeply perplexing questions of second-best compensation (Liberal State, pp. 24549 ), it will not help to wish these problems away by replacing the Everyman story with Fishkin's Everygod fantasy.

Fishkin has not convinced me, then, that my model of the power struggle can properly be called "arbitrary" (p. 352). He is right, however, to insist that mine may not be the only nonpreclusive way of describing the appropriate postHumean preconditions for justice-talk. It may be possible to produce a nonpreclusive model that analyzed Everyman's power struggle in a radically different wayone that described reality in terms that did not at all resemble the way I have used the basic descriptors in my model: "genes," "education," "manna," "transactional structure," "Everyman." The outcomes of Neutral dialogue in such a world would doubtless yield a very different conception of undominated equality-though it is hazardous to predict the differences until the rival model is produced.

\section{POSSIBLE SOLUTIONS}

If Neutral dialogue is the answer, what is the question? Not, says part 1 , the ultimate meaning of life-for that, each of us must seek enlightenment from 
those unconstrained conversations that seem worthwhile. Not, says part 2, the nature of the power struggle - for that, you must construct a model of the power struggle that does not preclude any problems of justice that may indeed arise in the real world. Well, then, what is the question?

It is this: does liberalism make sense as a systematic political philosophy?

A negative answer need not condemn the liberal enterprise. If all else fails, we may prepare an orderly retreat by reconceptualizing the field of dialectical struggle. Perhaps liberals should abandon the very search for an incisive and systematic theory of legitimacy. Despite our inability to define liberalism cogently, perhaps we should continue to commend it: the liberal should act in a liberal way at the liberal moment for liberal reasons. And so, after completing our praise of practical wisdom, we may lapse into comfortable bourgeois self-congratulation. Surely liberals, no less than other moderns, may learn to parody Aristotle with a show of conviction?

But before Aristotle, there was Plato-and his insistence upon exposing political ideals to a more intense, and systematic, dialogic test. And it is liberalism's questionable capacity to survive this kind of questioning that has always weakened it in its inevitable dialectical confrontation with authoritarian philosophy. Not that there haven't been liberal systems: but the most rigorous ones-like those of Hobbes or Bentham-achieve their system only by sacrificing much of liberal substance; while those philosophers who remain truer to the liberal spirit-say Locke or Mill-are notorious muddlers. This sad situation, authoritarians are quick to assure us, is no freak accident. They call upon us to have the strength of our dialectical convictions and discard comfortable creeds that survive only on our ability to tolerate gibberish. Serious people should not take the liberal's conversation stopper seriously-a concern with the liberal's penultimate question merely leads to an all-too-familiar jumble of self-contradiction. Instead, Deep Spirits must proceed at once to the master philosophical question of authoritarian politics - and debate the nature of the Ultimate Answer that should vanquish all the others in the ongoing struggle for power.

It was a principal aim of my book to deprive authoritarians of this cheap dialectical victory. However eager they may be to force their ultimate answers down our throats, they cannot evade the liberal's conversation stopper by saying that it leads only to meaninglessness. Despite their contempt for liberalism, you and I can continue to speak to one another in a coherent and mutually intelligible way about how we may legitimately organize our power struggle. It was the aim of ideal theory to describe the kind of world we might build together-if only our ability to transform the world were equal to our capacities to engage in liberal conversation. Have I been successful in this task?

It is premature to ask for a show of hands. Looking only at this symposium, however, the vote is: two yeses (Fishkin and Flathman), two abstentions (Barber and Williams) and no nos (an artifact of small sample size, undoubtedly).

Not that I take too much comfort from the yeses. As exemplary liberal critics, both Fishkin and Flathman bend over backward to distance themselves from their affirmations - to the point where the yeses are almost entirely lost in the shadows of qualification. Thus, Fishkin's essay triès to deprive ideal theory of its triumph by making the liberal victory seem almost too easy. While he concedes that the citizens of my ideal world can talk their way Neutrally to a system of undominated equality, he aims to show, by means of the arguments criticized in 
part 2 of this essay, ${ }^{7}$ that countless competing substantive ideals might gain an equal claim to liberal dialogic legitimacy.

Yet Fishkin's one-handed applause is positively deafening in comparison with Flathman's Delphic approval: “Ackerman's general answer is that all of the arguments for unequal distributions depend upon illegitimate claims to superiority. Thus equal distribution falls out as the only policy that does not breach the conversational constraints. I leave aside the question whether this argument would go through in a world blessed with Manna" (p. 361). Since Flathman is not widely known for his propensity to "leave aside a question" that reveals a theory's bankruptcy, I read this passage as a (tentative and revocable) acceptance of my central claim that liberal citizens would divide initial material resources equally under ideal conditions. Not that the liberal's commitment to initial material equality is absolute; material scarcity is only one source of the power struggle, and Everyman may properly insist on special compensation if he is denied his dialogic rights in one of the other basic power domains - genes, education, transactional structure. It is this fact that Flathman makes the centerpiece of his critique, which continues: "Ackerman does not have any Manna to distribute. The resources he is concerned to distribute as equally as the nature of the resources allow are such goods as genetic endowments, stable families, liberal education .... and so forth. In a world of finite resources, these goods compete with one another and with other goods ...” (p. 361). I agree. We must, as Flathman insists, face the hard fact that our world has not been created by a Liberal Maker trying to make our lives easy by providing all the skills and knowledge required for the ready implementation of liberal dialogue. What follows from this?

Flathman's answer: “This being the case, Ackerman's proposed allocations necessarily involve ranking of and choices among goods and hence among conceptions of good. The policies are grounded not in Neutrality among conceptions of good but in a preference for one conception of good over others" (p. 361). I disagree. Rather than permitting the existence of "second-best" conditions to serve as an excuse for imposing our ultimate solutions upon one another, an entire part of my book addresses the enormous gap between liberal ideals and their worldly application by liberal statesmen. Yet, although Flathman makes this point central to his critique, he explicitly refuses to consider my theory of liberal statesmanship. Thus, he fails to discuss the way in which the liberal theory of exploitation obligates statesmen to take aggressive action against the race, sex, and wealth domination that eats away at a liberal polity's dialogic legitimacy (Liberal State, chap. 8). Nor does he consider the way in which Neutral dialogue permits liberal statesmen to mediate their good faith disputes by adopting a distinctive form of liberal democracy-one in which a Supreme Court eliminates plainly exploitative outcomes, while a democratic process resolves the host of second-best compromises required by our imperfect technology of justice (Liberal State, chap. 9). Until Flathman takes these "casuistic" (p. 360) exercises seriously,

7. Fishkin also suggests that, even if my model of the power struggle were accepted, the principle of undominated equality would have at least one rival. According to Fishkin, the principle of equal satisfaction may also be supported in Neutral conversation (see Fishkin, this issue, p. 353). Space limitations do not permit a full analysis of this claim. For some of the relevant objections, see chap. 2 of Social Justice in the Liberal State and especially the problem posed by "jumping" considered at pp. 50-51. 
he has not earned the right to dismiss the role of Neutrality as a constraint upon second-best policy articulation.

No amount of moralizing, however will answer the master empirical question raised by liberal statecraft. In the words of Williams's A: "Do you believe that a liberal society could actually be sustained by the conception of life and human relationships which is presupposed by the relevance of Neutral dialogue?" (p. $370-71)$. A believes the answer is no. Unfortunately, however, he reaches this pessimistic conclusion by hoisting himself upon the very same false dichotomy that distorted Barber's critique. Just as Barber thinks that liberals can choose Neutral dialogue only by sacrificing the joys of unconstrained conversation, A says that liberalism "requires all of us to think, implicitly at least, that what we basically value about society is adequately expressed in what is appropriate to an emergency" (p. 370). This stripped-down conception of social life, A seems to think, is so impoverished that it could not sustain the loyalty and commitment of "any actual society" (p. 370).

The simple answer is that liberals are not committed, even "implicitly," to the impoverished vision of social life that haunts A's imagination. The liberal principle of conversational priority aims to affirm, not deny, the rich promise of social existence. By respecting each citizen's sovereign right to stop forms of ultimate communication he finds meaningless, we liberate ourselves for the hard task of elaborating those social forms that each of us do find significant. By cultivating the art of constrained conversation, liberal citizens create the cultural foundation for a society indescribably rich in its own characteristic forms of love, community, tragedy. It is true, of course, that, despite our best efforts, some of us will use our conversational freedom to discover a grimmer world-full of apathy, drift, and mediocrity. But no form of social existence, I fear, can credibly guarantee a meaningful life for everybody. Nor do I believe that political philosophy should lie about this hard truth and falsely promise all citizens paradise on earth. If Williams thinks this noble lie necessary for social stability-is this the implication of his finale?-he is more pessimistic than I am.

At the same time, he is more optimistic in assuming that everyday society can go on without confronting "emergency situations between people of widely diverse cultures" (p. 370). At the end of each day's work among the ivory towers, my walk home takes me past people who anxiously avoid my slightest nod of recognition-lest I discover them to be "illegal aliens" and report them to the governing authorities for prompt deportation. Indeed, were it not for these selfsame "authorities," I would be sharing my society with millions and millions more people-whose only "mistake" in life was their birth in New Delhi rather than New York, Canton rather than Cambridge. What are we to say to these people when they ask us why they may be excluded from our society?

Doubtless the liberal statesman's answer must be full of complex secondand-third-best casuistry (Liberal State, $\$ \S 20,56$ ). But it will not do for A to deny the existence of the problem. Indeed, even if we were to seal ourselves off from the billions of people who are so tendentiously said to inhabit a "third world," we still must confront very real and bitter disagreements with people who live closer to the place Williams calls "home." Despite his reassurances, I do not think that the need for liberal dialogue arises in rare "emergencies"; it is a constant political necessity for all who wish to make sense of the struggle for power that is our common fate. 
Not that there aren't emergencies so exigent that it would be almost silly to indulge in liberal second-guessing after the crisis has passed. Perhaps Barber's version of Harry Truman's A bomb dilemma qualifies as such a case. But I do not believe that the systematic, day-by-day suppression of billions of people in the name of the nation-state can ever qualify as an "emergency" which permits us to ignore the urgent questions of legitimacy raised by those denied their minimal dialogic rights.

\section{POSSIBLE REASONS}

The stakes are high enough, then, as we approach the final conversational turn: does it make sense to insist that power be mediated through Neutral dialogue?

In considering this question, we are no longer examining the kinds of argument that are admissible within the practice of liberal politics. What is at stake now is the justification of the entire practice of liberal argument, considered as a whole. Moreover, Hart and Rawls have taught us to recognize the importance of this shift in conversational key. As they have argued persuasively, ${ }^{8}$ there is no reason to insist that the reasons advanced in support of an entire practice be identical to those that are admissible within the practice. Applying their point to the present problem: while Neutrality excludes a broad range of normative argument from the practice of liberal politics, it does not follow that these arguments should also be excluded when the subject is the justification of the entire practice of liberal argument, considered as a whole. Indeed, it would be a category mistake to imagine that there could be a Neutral justification for the practice of Neutral justification-for Neutrality makes no sense except as a part of the practice it constitutes.

This familiar distinction between two kinds of justification may aid Williams's A in resolving his perplexities concerning the role of appeals to the good in liberal philosophy. To begin on common ground, I agree that "it is certainly not obvious that it is reasonable to expect a person to forget her conception of the good in discussing [the struggle for power]" (p. 369). Indeed, it is precisely for this reason that my book does not assert the "self-evident" rightness of Neutrality but, instead, presents a series of arguments on behalf of discursive self-restraint. Moreover, rather than asking Williams's A "to ignore" his conception of the good, the argument for Neutrality begins by assuming that each reader will initially find authoritarian politics attractive - so long, that is, as he can be assured that the authorities promote $h$ is conception of the good. It then tries to expose this naive belief to increasingly rigorous examination-first, by focusing on the practical difficulties involved in authoritarian government; second, by emphasizing the role of doubt in the pursuit of moral truth; third, by stressing the cardinal importance of autonomy in moral life; and fourth, by admitting a certain skepticism about the status of the good into the conversation (Liberal State, § 71).

Not, mind you, that this four-part argument offers the last word in the vindication of liberalism (see also Liberal State, §§ 7, 65-67). To the contrary, it is the first move in an ongoing dialogue with the reader. The aim is to provoke dialectical engagement and response-if the reader will explain why he finds

8. H. L. A. Hart, "Prolegomenon to the Principles of Punishment," in Punishment and Responsibility: Essays in the Philosophy of Law (Oxford: Oxford University Press, 1968), pp. 1-27; John Rawls, "Two Concepts of Rules," Philosophical Review 64 (1955): 3-32. 
each of the four arguments unpersuasive, these reactions may provide grist for the further dialogic defense of Neutrality; and on and on so long as the questioner finds further dialogue necessary to resolve his doubts about liberalism. In short, rather than fearing rigorous dialectical self-examination, the liberal's last, best, hope lies in the encouragement of philosophical reflection: "The only proper response to liberal political philosophy is more philosophy" (Liberal State, p. 370).

Noble sentiments, and perhaps misguided ones. Perhaps the more we investigate our views about the good, the more justified authoritarianism will seem. But perhaps not. The only way to find out is to keep on talking. There is a certain irony, then, in Williams's decision to adopt the dialogic form; for, despite a number of acute observations on other matters, the striking thing about his dialogue is its lack of dialectical engagement on the matter of liberalism's ultimate justification.

The persona Williams calls $\mathrm{A}$ is the philosophical heavyweight in the A-B duo. Yet, without considering any of the arguments I advance on behalf of Neutrality, A suggests that "it may not even be possible rationally to ignore [one's good in the ways required by the Neutrality constraint]" (p. 369). At another point, A dismisses Neutrality on the ground that: "It's a restriction that bans some judgments and not others, though all of them belong to the same dimension of assessment. It's like being allowed to discuss the merits of the weather, so long as you don't say that today's is better than yesterday's" (p. 368). But it is precisely my claim that there are fundamental reasons that $d o$ make it seem reasonable to constrain the way we should talk about our power struggles. Rather than chatting about the weather, the only way to do justice to this claim is to consider each of the arguments presented in The Liberal State and explain why each is unpersuasive.

Richard Flathman is more attentive than Williams's A. Of the four arguments for Neutrality emphasized in The Liberal State, Flathman confronts at least one of them-if only to note that my argument from liberal skepticism would hardly persuade the likes of Nietzsche. I am, however, less concerned with Nietzsche than I am with Flathman: Nietzsche, after all, is past his conversational prime, while Flathman is still struggling to make the best sense he can of politics. Can he explain how he has reasoned his way to a rejection of each of the arguments for Neutrality? If he can, perhaps he may find that we still have more to say to one another?

Flathman, however, takes a different tack. Rather than considering my four arguments on their merits, he commends a fifth to my attention-one of a broadly teleological kind. The ideal liberal state, he assures me, is not such an unattractive place; indeed, all things considered, it may be as good a society as it is plausible to imagine. Why not justify Neutral dialogue, then, on purely instrumental grounds? Perhaps Neutral dialogue is good because it produces the good society?

This is not, I must confess, my favorite argument in defense of liberalism. I myself prefer arguments which appraise social outcomes in terms of Neutral dialogue, rather than the other way around. While such deontological arguments can differ greatly from one another, they all serve to emphasize what, for me, is one of liberalism's great attractions: its effort to define the terms of social life in a way that does justice to each person's claim to moral independence. In contrast, a direct appeal to the goodness of liberal social ideals serves only to provoke, on a higher level, the liberal's distinctive question: While you say that Neutrality generates good results, $I$ think some un-Neutral outcomes would be better. And why is your judgment on this matter better than mine? 
The best way to counter this objection is to embrace it-for this may allow us to bring the questioner, through a dialectical process, to see that the concern for moral independence that motivates his initial question will, if taken seriously, lead him to embrace Neutrality on new and deeper grounds. No longer will it seem sensible to evaluate Neutral dialogue in terms of the good society it allegedly produces; constrained conversation will come to seem the essential cultural foundation for each person's effort to make sense of the good in a way that does not impugn the like effort of his fellow communicants.

My difficulty with Flathman's teleological argument also expresses itself on the level of terminology. I think it misleading to talk as if social outcomes, considered independently of dialogic processes, could be evaluated in terms of Neutrality-even when Neutrality is modified by the subscript ${ }_{1}$. So far as I am concerned, there is no such thing as a Neutral ${ }_{1}$ outcome: all outcomes, taken by themselves, are best described as "frustrating" for some citizens-even when they are fulfilling for others. The aim of Neutrality is not to eliminate the pain and disappointment that come with living in society; it is, instead, to permit us to talk about our frustrations in a particular way. While, doubtless, I could have chosen a less provocative word to describe the particular conversational form favored by liberals, Flathman's decision to call it Neutrality ${ }_{2}$ does not strike me as provocative enough: especially since I reject the effort to judge outcomes in terms of a Neutrality ${ }_{1}$ that is divorced from dialogic processes.

But all of this, I hasten to add, is only one liberal's opinion. As I emphasized in my closing chapter, I have no desire to excommunicate citizens simply because they think it reasonable to travel down one, rather than another, of the dialectical paths that lead to liberalism's ultimate justification (Liberal State, §70). So long as Flathman reaches Neutrality by a route he considers reasonable, there can be no question of forcing him to change his mind-unless, that is, he is persuaded by further philosophical conversation to announce his deontological conversion. Indeed, the philosophical debate between teleologists and deontologists can proceed endlessly-so long as no teleological philosopher moves beyond talk to threaten the rights guaranteed others as citizens of a liberal state. It is only when teleology becomes authoritarian coercion that the moment of truth arises: will we have the good sense to distinguish the liberal statesman from the authoritarian demagogue? Will we have the courage to support our liberal convictions with our lives, if necessary?

\section{WHAT IS NEUTRAL ABOUT NEUTRALITY?}

I do not write for Neutral readers, simply thoughtful ones. I do not hope for Neutral outcomes, only meaningful ones. I do not aim for Neutral accounts of the power struggle, merely accurate ones.

Neutrality is a way of talking. It is not the only way; nor even the way that does justice to the full complexity of each person's search for meaning and fulfillment.

Yet it is not to be disdained. Despite our best efforts, we cannot ignore the presence of earthly creatures who have learned to pronounce alien meanings upon the mystery of the universe. In one way or another, we must learn to deal with our competitors in the struggle for power. A first response is to persuade them to abandon their errors and adopt our truths; a second, to convince them that toleration is in their self-interest; a third, to induce them to sympathize with 
us, despite the error of our ways. But is there a fourth way-a way we may travel together when, to our dismay, the others lead nowhere?

Yes: we can speak Neutrally to one another when we find we have nothing better to say. The dialogic effort does not lead to self-contradictory gibberish but to a form of community that, for all its difficulties, permits us to sustain communication without lying about our ultimate disagreements.

And if we disdain the art of constrained conversation, how will we come to terms with one another?

Is there a fifth way beyond excommunication and brute suppression? 